\title{
No Provision Left Behind - Law of the Sea Convention's Dispute Settlement System and Obligations Erga Omnes
}

\author{
Eirini-Erasmia Fasia \\ Faculty of Law, University of Oxford, Oxford, UK \\ eirini-erasmia.fasia@law.ox.ac.uk
}

\begin{abstract}
The article argues that the Law of the Sea Convention's (LOSC) dispute settlement system (DSs) is attuned only to certain types of disputes (bilateral) and does not allow for the effective enforcement of obligations erga omnes reflected in the Convention. Mechanisms established to address enforcement of communitarian norms specifically are scarce in international law and the traditional bilateral structure of adjudicatory dispute settlement circumscribes the ability of states to act as advocates of the international community to which obligations erga omnes are owed. The article identifies the obligations erga omnes reflected in the LOsC and assesses the extent to which its dispute settlement framework is suited to address their breach. It is submitted that some of the community interest obligations of the LOSC are "left behind" by the function of the system itself.
\end{abstract}

\section{Keywords}

erga omnes - enforcement - Law of the Sea Convention - dispute settlement

The present article argues that the Law of the Sea Convention's (LOSC) dispute settlement system (DSs) does not allow for the effective enforcement of 
obligations erga omnes reflected in the Convention. ${ }^{1}$ The Losc's traditional bilateral adjudicatory proceedings are designed as a means to vindicate claims in the context of bilateralized disputes. This requires multilateral obligations to be reduced to a bilateral relationship between states in order to be pursued in the context of adjudication. The bilateral structure of adjudicatory dispute settlement thus circumscribes the ability of states to act as advocates of the international community to which obligations erga omnes are owed. ${ }^{2}$

Erga omnes is the legal term associated with international obligations in the "community interest" and was recognised as part of international law by the International Court of Justice (ICJ) in the 1970 Barcelona Traction judgment. Obligations erga omnes are owed to the international community (of states) as a whole and thus, all states are allowed to invoke the violation and take enforcement measures for their observance in the event of breach. Enforcement includes institutional dispute settlement and is not limited to quasi-physical action through decentralized measures undertaken by individual states or groups of states. ${ }^{3}$

The problems that may arise when attempting to enforce erga omnes obligations through traditional bilateral dispute settlement frameworks are by no means unique to the law of the sea. Contemporary international law increasingly reflects interests that go beyond the narrow relations between states, ranging from human rights to the protection of the environment. ${ }^{4}$ However, mechanisms established to address enforcement of communitarian norms specifically are still scarce, and thus, such norms are often left to be interpreted and applied in the context of adversary and bilateral proceedings.

1 United Nations Convention on the Law of the Sea (adopted 1o December 1982, entered into force 16 November 1994), 1833 U.N.T.S. 3.

2 A. Paulus, "International Adjudication", in S. Besson and J. Tasioulas (eds.), The Philosophy of International Law (ouP, 2010), 253; M. Benzing, "Community Interests in the Procedure of International Courts and Tribunals", 5 L.P.I.C.T. (2006), 369, 376; Ch. Tams, "Individual States as Guardians of Community Interests", in U. Fastenrath et al. (eds.), From Bilateralism to Community Interest - Essays in Honour of Judge Bruno Simma (OUP, 2011), 387.

3 A. Tzanakopoulos, E. Methymaki, "Another Brick in the Wall - Reflexivity of the Sources and the Enforcement of International Law: Domestic Courts as Sources and Enforcers", in S. Besson and J. d'Aspremont (eds.), The Oxford Handbook on the Sources of International Law (ouP, 2017); R. Jennings, "Judicial Enforcement of International Obligations", 47 ZaöRV (1987), 3; Cf. Ch. de Visscher, "Méthode et Système en Droit International" (1973) 138(II) Recueil des Cours $9,137-153$ for a narrow understanding of enforcement as measures to induce or compel compliance.

4 See generally U. Fastenrath et al. (eds.), From Bilateralism to Community Interest, Essays in Honour of Bruno Simma (OUP, 2011). 
The bilateralization of such obligations is not always successful and fails to express the multilateral character of the obligation.

The LOSC is a convenient case study for that matter because as an instrument it was designed partly to accommodate the individual interests of states in their marine affairs and partly to express and protect the general community interests in the oceans. Hence, the Losc consists of an abundance of rules, ranging from bilateral obligations to rules adopted in the general interest. Notwithstanding its erga omnes elements, however, the Convention still reflects a largely bilateral-based framework when it comes to dispute settlement. Most disputes that find their way to the LOSC DSs are bilateral, whereas even when states bring cases in which obligations erga omnes have been relied upon, this really occurs in the context of a dispute that states have treated as if it was bilateral (bilateralized). As a result, some of the non-bilateral obligations of the LOSC seem to be "left behind" by the function of the system itself. In other words, there seems to be a disconnect between the broad scope of obligations erga omnes in the Convention, expressive of its community aspect, and its ability to provide a mechanism for their recognition and enforcement, thus limiting their legal effects.

The article is divided into four sections. Section 1 provides an overview of obligations erga omnes in international law. Based on the criteria discussed in Section 1, Section 2 aims to identify obligations erga omnes embodied in the LOSC. Section 3 reviews the structure of Part V (DSS) of the LOSC and revisits relevant cases, seeking to determine whether the DSs is attuned only to certain types of disputes. Finally, Section 4 briefly explores potential alternatives for the enforcement of obligations erga omnes in the law of the sea context and in international law more generally.

International obligations "may be owed to another state, to several states, or to the international community as a whole." Obligations that are owed to the international community as a whole and whose breach concerns all states are erga omnes. This category establishes a special regime of standing allowing every state to claim non-compliance, via permissible means, such as claims before political organs of international organizations, judicial claims, or

5 Article 33 ILC Draft Articles on Responsibility of States for Internationally Wrongful Acts (2001) reproduced in: Report of the ILC on the Work of its 53rd Session, UN Doc. A/56/10, 43 (hereinafter: ARSIWA). 
countermeasures, irrespective of whether that state has suffered any damage. ${ }^{6}$ Rules governing standing may be treaty-based (e.g., Article 94 LOSC) or customary (e.g., Article 42 ARsiwA). ${ }^{7}$

The most unproblematic way to establish standing is through unequivocal treaty provisions that stipulate which state has standing to respond to breaches of the law. During the eighteenth and nineteenth centuries international law was largely bilateral in character, in the sense that multilateral treaties were comprising exchanges of bilateral promises. ${ }^{8}$ The example that is often used is that of the Vienna Convention on Diplomatic Relations, a multilateral Convention which establishes bundles of bilateral relations, and the obligations are to be observed between pairs of receiving and sending states. 9 This practice gradually changed, and international law began to include multilateral obligations that are held in common by a group of states as such. ${ }^{10}$ This shift gave rise to complexities with respect to whether states can enforce obligations that are not owed exclusively to them, especially when there is no treaty provision stipulating, for example, that all states can respond against

6 Ch. Tams, Enforcing Obligations Erga Omnes in International Law (CUP, 2005), 28-32, 40; See also C. Dominice, "The International Responsibility of States for Breach of Multilateral Obligations", 10(2) E.J.I.L. (1999), 353; J.A. Frowein, "Reactions by Not Directly Affected States to Breaches of Public International Law" (1994) 248(IV) Recueil des Cours, 345; G.I. Hernandez, "A Reluctant Guardian: The International Court of Justice and the Concept of International Community", 83(1) B.Y.I.L. (2013), 13, 43; A. Vecchio, "International Courts and Tribunals, standing" (Max Planck Encyclopedia P.I.L., 2010); Reparation for Injuries Suffered in the Service of the United Nations (Advisory Opinion) (1949), paras. 181-182.

7 Ch. Tams (2005), supra note 6, 38; D. Azaria, "The European Union's Contribution to the Law on Standing and Jurisdiction in International Dispute Settlement", in M. Cremona et al., The EU and International Dispute Settlement (Hart, 2017), 57.

8 W. Riphagen, Third Report (1982) II/1 Yrbk I.L.C. 38, para. 97; Tams (2005), supra note 6, 48; G. Nolte, "From Dionisio Anzilotti to Roberto Ago: The Classical International Law of State Responsibility and the Traditional Primacy of a Bilateral Conception of Inter-state Relations", 13(5) E.J.I.L. (2002), 1083; W. Grewe (M. Byers), The Epochs of International Law (Walter de Gruyter, 200o); M. Koskenniemi, The Gentle Civilizer of Nations; The Rise and Fall of International Law (CUP, 2002); J. Crawford, "Multilateral Rights and Obligations in International Law" (2006) 319 Recueil des Cours 407; B. Simma, "Bilateralism and Community Interests in the Law of State Responsibility", in Y. Dinstein (ed.), International Law at a Time of Perplexity, Essays in Honour of Shabtai Rosenne (Springer, 1989), 822-823. Vienna Convention on Diplomatic Relations (adopted 18 April 1961, entered into force 24 April 1964), 500 U.N.T.S. 95; see also the recent ICJ case between Equatorial Guinea and France, Immunities and Criminal Proceedings (2020).

10 A. Sicilianos, "The Classification of Obligations and the Multilateral Dimension of the Relations of International Responsibility", 13(5) E.J.I.L. (2002), 1127, 1135; G. Fitzmaurice, 2nd Report on the Law of Treaties (1957) 16(II) Yrbk I.L.C.; see also D. Azaria, Treaties on Transit of Energy via Pipelines and Countermeasures (OuP, 2015), Chapter 4. 
treaty breaches irrespective of individual damage. In the 196os there was a heated debate in the ICJ regarding Ethiopia's and Liberia's standing to pursue a claim against South Africa for breaches of the Mandate for South-West Africa. The majority in 1962 had no difficulty with the fact that Ethiopia and Liberia were seeking to vindicate a public interest claim, not relying on individual rights. But in 1966 the Court adopted a narrow view and held that the claim was inadmissible precisely because it did not involve individual rights of the applicant states. ${ }^{11}$

It was the ICJ that introduced the concept of obligations erga omnes in international law by distinguishing obligations which are owed collectively to the international community as a whole from obligations which are owed individually to states. Paragraphs 33 to 34 of the Barcelona Traction judgment refer to a category of state obligations "towards the international community as a whole", which by nature are "the concern of all states", in the sense that "all states can be held to have a legal interest in their protection" "because of their importance."12 The Court did not expressly vindicate that standing is a consequence of the status of a norm as erga omnes. However, it implied that if only the state of nationality enjoys standing to bring claims for obligations arising under the doctrine of diplomatic protection, a contrario this does not apply in the case of obligations erga omnes. The Barcelona Traction obiter dictum was recognised by the majority in the Nuclear Tests case as indicating general rules on standing, ${ }^{13}$ while in East Timor the ICJ affirmed the erga omnes nature of the right to self-determination. ${ }^{14}$

The International Law Commission (ILC) expressly provided for the possibility of invocation of responsibility in the public interest. ${ }^{15}$ Article 48 ARSIWA creates a broad circle of other states entitled to invoke responsibility and recognizes that states other than injured states have a legal interest in the performance of certain multilateral obligations and can invoke state responsibility

11 SouthWest Africa (second phase) (1966), paras. 18, 25-27.

12 Barcelona Traction (1970), paras. 33-34; P. Picone, "The Distinction between Jus Cogens and Obligations Erga Omnes", in E. Cannizzaro (ed.), The Law of Treaties Beyond the Vienna Convention (OUP, 2011), 3; S. Villalpando, "The Legal Dimension of the International Community: How Community Interests are Protected in International Law", 21(2) E.J.I.L (2010), 401.

13 Nuclear Tests (Australia v. France) (1974), Diss. Op. of Judge Sir Garfield Barwick, 437; Joint Diss. Op. of Judges Onyeama, Jiménez de Aréchaga and Sir Humphrey Waldock, para. 118; Cf. Diss. Op. of Judge de Castro rejecting the view that all states have standing in disputes involving erga omnes obligations (Nuclear Tests (Australia v. France) (1974)), para. 387.

14 East Timor (1995), para. 29.

15 ARSIWA Commentary expressly takes into consideration the Court's pronouncement in Barcelona Traction: Article 1, at para. 4. 
in the collective interest. ${ }^{16}$ Article $48(1)(b)$ refers to obligations owed to the "international community as a whole." The term erga omnes is avoided because according to the ILC it would not have been very enlightening. ${ }^{17}$ Article 48 is not mutually exclusive with Article 42 ARSIWA, and it can occur that individual states are specially affected by the breach of obligations erga omnes. ${ }^{18}$

At this point, it is crucial for our inquiry to address the distinction often made between obligations erga omnes and obligations erga omnes partes (Article 48(1)(a) ARSIWA). The latter are said to be (mainly) treaty-based obligations distinguished from obligations erga omnes that derive from general international law. The distinction allegedly emanates from paragraph 34 of Barcelona Traction which suggests that [such obligations] "have entered into the body of general international law [...]"; and "others are conferred by international instruments of a universal or quasi-universal character." Tams, however, argues that the wording of the Court does not imply a distinction, but rather it is used to enhance the content of obligations erga omnes. Thus, the passage is best interpreted as an indication that obligations erga omnes are sometimes protected by international treaties as well. ${ }^{19}$ Of course, treaties such as the European Convention on Human Rights (ECHR), the International Covenant on Civil and Political Rights (ICCPR) or the Convention against Torture (CAT) set out obligations erga omnes partes, some of which may also be erga omnes, for example, the prohibition of torture. The continuous value of the erga omnes partes concept is then centred on the fact that some cases will be brought to the judiciary through a treaty compromissory clause, and courts/tribunals will feel more comfortable to find legal interest based on the erga omnes partes concept than delve into a debate whether the obligations

16 Similarly, Article 52 Draft Articles on Responsibility of International Organizations, ILC, Responsibility of International Organizations, Report of the Drafting Committee adopted on the work of its Sixtieth session, A/CN.4/L.725, 3-4.

17 ARsiWA Commentary, Introduction to Part 3, Chapter 1, paras. 9, 2.

18 ARsiwA Commentary, Introduction to Part 3, Chapter 1, para. 3 and Article 48, para. 10; see also P. Birnie, A. Boyle, C. Redgwell (eds.), International Law and the Environment (oup, 2009), Chapter 4, section 2.5.

19 Tams (2005), supra note 6, 120-128; ARsiwa Commentary on Article 48, para. 6; Crawford, 3rd Report, para. 106(b); Hernandez (2013), supra note 6, 42, fn. 16o; Cf. Sicilianos (2002), supra note 10, 1135-1137. See also Belgium v. Senegal (2012), para. 68; Whaling in the Antarctic (Australia v. Japan: New Zealand intervening) (2014); Cf. Belgium v. Senegal (2012), Sep. Op. Judge Owada, paras. 15-23 and Diss. Op. of Judge Xue and Judge ad hoc Sur, paras. $13-23$ and $26-46$ respectively. 
in question are erga omnes. ${ }^{20}$ If a treaty already provides for enforcement, then reliance by the parties on the general enforcement powers deriving from the erga omnes concept might not be necessary. ${ }^{21}$ If a treaty deviates from the general rules on standing associated with the erga omnes concept, then a discussion on exclusivity or complementarity in competing enforcement regimes would be pertinent. However, this is not the case with the LOSC and its Dss.

With regard to remedies, Article 48(2)(a) ARSIWA provides that states other than the injured state may seek the cessation and assurances of non-repetition of the wrongful act, and (b) "performance of the obligation of reparation [...] in the interest of the injured State or the beneficiaries of the obligation breached". Restitution and satisfaction are thus reserved for the directly injured states. ${ }^{22}$ Beyond remedies, other kinds of care might also be given to the protection of the community interests safeguarded by erga omnes obligations. For instance, Article 290(1) LOSC gives the ICJ or tribunals, or the International Tribunal for the Law of the Sea (ITLOS), the power to prescribe provisional measures with the sole purpose of protecting the marine environment (including the conservation of fisheries). ${ }^{23}$ This "extra" competence, in an already as expeditious procedure as the one of provisional measures, can fundamentally contribute to the enforcement of marine environmental obligations.

Regarding the identification process, although obligations erga omnes have become part of the contemporary international law language, ${ }^{24}$ there is still no clear method on how rules enter into this "magic circle." 25 The ICJ has been rather opaque on the process whereby it "beatifies" obligations as erga omnes ${ }^{26}$ and has provided a limited number of examples. To date the list provided by

20 See reference to erga omnes partes in Application of the Convention on the Prevention and Punishment of the Crime of Genocide (The Gambia v. Myanmar), ICJ, Order (23 January 2020).

21 In the case of the LOSC, it would depend on the interpretation of the relevant provisions and provisions of Part Xv; Ch. Tams, A. Tzanakopoulos "Barcelona Traction at 40: The ICJ as an Agent of Legal Development", 23 L.J.I.L. (2010), 794; Cf. E. de Wet, "Jus Cogens and Obligations Erga Omnes", in D. Shelton (ed.), The Oxford Handbook of International Human Rights Law (OuP, 2013).

22 Arguably non-injured states may also exercise collective counter-measures pursuant to Article 54 ARSIWA.

23 The disjunctive "or" in the text of the provision that the environmental objective can be relied on exclusively.

24 Y. Tanaka, "Protection of Community Interests in International Law: The Case of the Law of the Sea", 15 Max Planck Yrbk U.N.L. (2011), 329, 332-333.

25 M. Reisman, “Comment”, in J. Delbrück (ed.), The Future of International Law Enforcement: New Scenarios - New Law? (Duncker \& Humblot, 1993), 168.

26

Tams (2005), supra note 6, 118 . 
the Court includes the prohibition against aggression, slavery, racial discrimination, and genocide, ${ }^{27}$ as well as the right of people to self-determination ${ }^{28}$ and rules of international humanitarian law that embody "elementary considerations of humanity."29 It would have been interesting to see whether the ICJ - if it had upheld its jurisdiction - would have affirmed the existence of an obligation erga omnes to nuclear disarmament. ${ }^{30}$

One can observe a relation of obligations erga omnes to jus cogens norms. These two categories are sometimes erroneously perceived as identical. Although all peremptory norms do create obligations erga omnes, not all obligations erga omnes derive from peremptory norms and by no means share the same superior status as jus cogens. ${ }^{31}$ Nor do obligations erga omnes stand somewhere in the middle of peremptory and non-peremptory norms of international law "constituting a second layer of the international value system, below that of peremptory norms." ${ }^{32}$

27 Barcelona Traction (1970), para. 34; Genocide case (Bosnia and Herzegovina v. Serbia and Montenegro) (Preliminary Objections) (1996), para. 616; Genocide case (Bosnia and Herzegovinav. Serbia and Montenegro) (2007), para. 104; Armed Activities (New Application: 2002) (Democratic Republic of the Congo v. Rwanda) (Jurisdiction, Admissibility) (2006), para. 64 .

28 East Timor (1995), para. 29; Wall, Advisory Opinion (2004), para. 88; Legal Consequences of the Separation of the Chagos Archipelago from Mauritius in 1965, Advisory Opinion (2019), para. 18 o.

29 Wall, Advisory Opinion (2004), paras. 155, 157.

30 Marshall Islands v. United Kingdom case, Marshall Islands v. India case, Marshall Islands v. Pakistan case (Institution of Proceedings) (2014); see also: Gabčikovo case (1997), Sep. Op. of Judge Weeramantry, 88, 117-118; Nicaragua case (Nicaragua v. United States) (Provisional Measures) (1984), Diss. Op. of Judge Schwebel, 196; Wall, Advisory Opinion (2004), 172, 199; Genocide case (Bosnia and Herzegovina v. Serbia and Montenegro) (Provisional Measures) (1993), Sep. Op. of Judge ad hoc Lauterpacht, 440; Armed Activities (Democratic Republic of the Congo v. Uganda) (Counter-claims) (2005), Sep. Op. of Judge Simma, 334, 349-35o.

31 G. Gaja, "The Protection of General Interests in the International Community" (2014) 364 Recueil des Cours, 56; K. Zemanek, "New Trends in the Enforcement of Erga Omnes Obligations", 4(1) Max Planck Yrbk U.N.L. (2000), 6; M. Byers, "Conceptualising the Relationship between Jus Cogens and Erga Omnes Rules”, 66(2) Nordic J.I.L. (1997), 211, 212; Tams (2005), supra note 6, 149 .

32 E. de Wet, "The Emerging International Constitutional Order", 2 Potchefstroom E.L.J. (2007), 9. See similar claims cited in Linderfalk (2011); M. Shaw, International Law (CUP, 2008), 124: Obligations erga omnes are "of a different or higher status than others"; A. de Hoogh, "The Relationship Between Jus Cogens, Obligations Erga Omnes and International Crime: Peremptory Norms in Perspective”, 42 Austrian J. Pub. Int'l L. (1991), 192: "obligations of a higher normative value"; J. Delbrück, "Laws in the Public Interest: Some Observations on the Foundations and Identification of erga omnes Norms in International Law", in V. Götz, P. Selmer and R. Wolfrum (eds.), Liber Amoricum Guinther Jaenicke zum, 85. Geburtstag (Springer, 1998), 35: "Erga omnes norms are a new element 
Further, although obligations erga omnes are carrying an element of protecting values and concerns of increased importance, it is inaccurate to identify obligations as erga omnes based on the fundamental interest or value they supposedly protect. ${ }^{33}$ Such a criterion would be entirely subjective, especially because open-textured phrases like "community interests", "fundamental values", "common concerns" and so on are not technical terms. ${ }^{34}$ The erga omnes nature of a particular obligation is related not to the substance of the obligation but to the question of who has the right to complain against its violation..$^{35}$ Of course, rules that give standing to all states will probably reflect "important" interests for the international community as a whole but the existence of a community interest or value flows from the fact that standing is granted to all states and not the other way around. On the other hand, the exclusive reliance on the question of legal standing to identify erga omnes obligations may give rise to problems too. Tanaka notes that obligations erga omnes are not the only ones that bind simultaneously each and every state concerned with respect to all others, bringing the example of obligations to secure certain standards of safety at sea. ${ }^{36}$ Thus, he argues that a conjunctive approach is necessary according to which whether an obligation is regarded as an obligation erga omnes would vary depending both on the interpretation of the concept of community interests and the non-reciprocal character of obligations. ${ }^{37}$ However, as long as the content of the concept of community interests is not established in international law, this approach does not make the identification of obligations erga omnes any easier in practice.

in the hierarchy of international law". See Commentary, Part II, Chapter III, para. 7: "Whether or not peremptory norms of general international law and obligations to the international community as a whole are aspects of a single basic idea, there is at the very least substantial overlap between them".

33 Villalpando, supra note 12, 387; B. Simma, "Universality of International Law from the Perspective of a Practitioner", 20(2) E.J.I.L. (2009), 265, 274; G. Blum, "Bilateralism, Multilateralism, and The Architecture of International Law", 49 Harv. Int'l L.J. (2008), 323, 357; see also Hernandez (2013), supra note 6, 13. The IDI has defined erga omnes as "obligations under general international law that a state owes in any given case to the international community, in view of its common values and its concern for compliance, so that a breach of that obligation enables all states to take action." IDI, "Obligations Erga Omnes in International Law" (2005) Resolution of the Krakow Session, Rapporteur G. Gaja, Article 1 (a).

34 I. Feichtner, "Community Interest" (2007), Max Planck Encyclopedia P.I.L.

35 J. Crawford, "Responsibility for Breaches of Communitarian Norms, an Appraisal of Article 48", in U. Fastenrath et al. (2011), 230.

36 Y. Tanaka, "The Legal Consequences of Obligations Erga Omnes in International Law", 68 Netherlands International Law Review (2021), 1-33, 8.

Ibid., 9-10, 18. 
Admittedly, when moving beyond jus cogens, the identification of obligations erga omnes becomes considerably more difficult and erga omnes outside jus cogens is likely to remain unexplored waters until states begin to invoke the concept more frequently in formalised proceedings. Indeed, both the ICJ and the ILC have predicted that "the scope of the concept will necessarily evolve over time."38

\section{3}

\section{Obligations erga omnes in the Law of the Sea Convention}

So far, it has been determined that obligations erga omnes are customary multilateral obligations, reflective of community interests and "vested with a special regime of standing that allows the protection by each and every state". ${ }^{39}$ The Law of the Sea Convention is a combination of different types of international rules, with obligations erga omnes being part of the blend. ${ }^{40}$ The law of the sea is a matrix of individual and community interests of states, ranging from allocating jurisdiction in different maritime zones to general provisions aiming for the protection of the marine environment and the conservation of its resources. This wide spectrum of objectives inevitably brings together obligations of variable normative content. Like most multilateral treaties, the LOSC does not contain express rules on standing nor does it pronounce on the legal nature of its obligations. Hence, the identification is a matter of interpretation of the relevant provisions and can be determined by answering questions like upon whom the obligations are imposed, who can invoke them, and who is injured by their breach. ${ }^{41}$

It is argued that the obligations erga omnes reflected in the Losc relate to the prohibition of the use of force and slavery, the freedom of navigation, the

38 ARsiwA, Commentary, para. 9; Barcelona Traction (1970), para. 34: "for example." Tams has also optimistically maintained that identifying erga omnes obligations "will usually not present unsurmountable problems", in Tams (2005), supra note 6, 157 .

39 Ch. Tams, A. Tzanakopoulos (2010), supra note 21, 792.

40 The Convention reflects custom to a great extent. Qatar and Bahrain (Merits) (2001), para. 167; Nicaragua v. Colombia (Merits) (2012), para. 114; A. Roach, "Today's Customary International Law of the Sea", 45(3) O.D.I.L. (2014), 239.

41 ARSIWA, Commentary 118(6); G. Fitzmaurice, 4th Report on the Law of Treaties (1959), A/CN.4/120 (II), Yrbk I.L.C. 54, 18 referred to the "correct interpretation of the treaty according to its terms" in order to identify the nature of obligations therein; see also, Crawford (2011), supra note 35, 238-239: "[ $t$ ] he question of interpretation in light of general international law within the meaning of Article 31(3)(c) VCLT becomes crucial in the absence of an explicit clause recognizing the legal interest and standing of all States." 
protection of the marine environment and conservation of marine natural resources, and the legal regime governing the Area.

The obiter dictum in Barcelona Traction refers to obligations that derive from the outlawing of acts of aggression and principles concerning the basic human rights, such as the prohibition of slavery. ${ }^{42}$ These obligations have already been pronounced as erga omnes by the ICJ. Articles 88 and 141 LOSC reserve the use of the High Seas (Hs) and the Area exclusively for peaceful purposes, whereas Article 301 provides for an obligation of a similar wording to that of Article 2(4) of the UN Charter. To the extent that Article 2(4) is of a jus cogens character and, hence, an erga omnes rule, the very same legal nature permeates the corresponding LOSC provisions. ${ }^{43}$ By the same token, Article 99 that prohibits the transport of slaves with a view to combat slavery at sea similarly operates as an erga omnes rule. The right of visit under Article 110 is a further right that the LOSC vests states with. It is an enforcement power given to warships in order to combat inter alia slave-trade, which does not affect the erga omnes nature of the rule. ${ }^{44}$

Further, the freedom of navigation and communication, governing the Hs, is one of the classical examples of a "communitarian norm", identified by Grotius as "a right which equally appertaineth to all nations". ${ }^{45}$ The Permanent Court of International Justice (PCIJ) in the S.S. "Wimbledon" case allowed for claims to be brought by Italy and Japan against Germany in relation to its obligation not to refuse access to the Kiel Canal, even though the former were not individually injured. The Court concluded that states enjoy freedom of navigation in the Kiel Canal, as it "has been permanently dedicated to the use of the whole world". ${ }^{46}$ In a similar vein, in the Nuclear Tests case, Australia and New Zealand argued before the ICJ that "such interference with ships and aircraft on (and over) the Hs [...], constitute infringements of the freedom of the Hs", without arguing that they were specially affected by France's violations. ${ }^{47}$ Indeed, given that about ninety percent of world trade is transported by sea, the freedom of maritime navigation will always be a subject of heightened concern among

42 Barcelona Traction (1970), para. 34.

43 UNGA Report of the Secretary General, "Study on the Naval Arms Race”, A/4o/535 (1985), para. 188; Nicaragua case (Nicaragua v. United States) (Merits) (1986), paras. 190-191.

44 E. Papastavridis, The Interception of Vessels on the High Seas (Hart, 2013), Chapter 3.

45 Crawford (2011), supra note 35, 228, referring to H. Grotius, Mare Liberum (16o9, reprinted by Liberty Fund, 2004), Chapter I, 11.

46 S.S. "Wimbledon" (Great Britain and others v. Germany) (Judgment of 17 August 1923), PCIJ Rep. Series A No. 1, 22; see also Corfu Channel (Merits) (1949), 22.

47 Nuclear Tests (Australia v. France), ICJ, Pleadings, Oral Arguments, Documents, Vol. I (1978), 14. 
states. Illustrative of the collective nature of the freedom of navigation is the case of straits used for international navigation, such as the Hormuz Strait. ${ }^{48}$ Iran has repeatedly threatened to close the Strait of Hormuz, thus cutting off many states from oil importing activities. ${ }^{49}$ Hormuz is a strait used for international navigation, falling within the scope of Article 38(1) LOSC, which provides that "all ships and aircraft enjoy the right of transit passage, which shall not be impeded." Article 44 LOSC provides that states bordering straits must abstain from hampering transit and are required to disclose information regarding a possible threat to navigation in the strait. Third states enjoy the right of "transit passage" in the straits, which gives them navigating rights similar to those emanating from the principle of the freedom of navigation. All states have thus standing to protest and react against Iran's conduct. If a vessel with the flag of state $\mathrm{X}$ was stopped entering the strait, then that would result in a bilateralizable dispute, but this would not prevent other states from acting under Article 48 ARsiWA. ${ }^{50}$ This analysis can be sustained if we accept that the LOSC regime on straits used for international navigation reflects custom, or rather that the regime governing straits outside the LOSC is that of freedom of navigation: Iran is a signatory to the Convention without having yet ratified it, which makes custom the only applicable law.

Moving on to the marine environment, customary obligations arising out of environmental objectives are commonly perceived as owed to all states of the international community and wrongdoers may be held responsible for non-compliance, even if the violations do not per se affect the rights of an individual state, but rather those of the community as a whole. ${ }^{51}$ The LosC contains an exclusive part (XII) on the protection of the environment. In particular, Article 192 which is a general environmental obligation, the content of which is further detailed in the subsequent provisions of Part XII or in other international agreements, is widely regarded as an obligation erga

48 M. Waechlish, "The Iran-US Dispute, the Strait of Hormuz and International Law", The Yale J. Int'l L. (2012), 22, 23.

49 B. Salinaite, S. Kirchner, "The Iranian Threat to Close the Strait of Hormuz: A Violation of International Law", 20(2) Jurisprudence (2013), 552-557; C. MacDonald, "Iran's Strategic Interests and the Law of the Sea", 34(3) M.E.J. (1980), 302.

$5^{\circ}$ ARsiwa, Commentary on Article 48(2), para. 12.

$5^{1}$ See Birnie, Boyle, Redgwell (2009), supra note 18, 99-100, 132; H. Xue, Transboundary Damage in International Law (CUP, 2003), 237-250; A. Kiss, D. Shelton, International Environmental Law (Kluwer, 2003), 24-25; E. Uhlmann, "State Community Interests, Jus Cogens and Protection of the Global Environment: Developing Criteria for Peremptory Norms", 11 Geo. Int'l Envt'l L. Rev. (1998), 101; Nuclear Tests cases (1974), 253 and 457 respectively. 
omnes. ${ }^{52}$ The importance that the Convention attributes to the protection of the environment is also exemplified by the provision of Article 218 which recognises a right of port states to exercise enforcement jurisdiction over certain discharge offences that took place in any part of the sea, outside the national jurisdiction of that state and regardless of direct damage to the port state. ${ }^{53}$ Essentially, Article 218 recognises the right of states to exercise jurisdiction in defence of the general interest of protection of the marine environment, providing an important exception to the principle of exclusive flag state jurisdiction on the Hs (Article 94 LOSC). Whereas all states have a legal interest in seeing obligations erga omnes observed, treaties sometimes explicitly delegate enforcement competences to specific actors recognizing their special role. Although Article 218 may extend the jurisdiction of port states, it remains silent on the rights of other states. Provisions like this should be seen as complementary to and enhancing the erga omnes effect of general obligations. ${ }^{54}$ Here, the Convention entrusts the role of (physical) enforcement agents to coastal states, without implying that flag states are deprived of this power. ${ }^{55}$ Generally, a state seeking to defend legal interests owed to the international community will need to base its enforcement actions on the erga omnes concept, except if a treaty operating as lex specialis derogates from it.

The duty to protect and preserve the marine environment comprises the conservation of living marine resources, as the former is an inclusive concept

52 A. Proelss, Commentary, 1285, 1286; Birnie, Boyle, Redgwell (2009), supra note 18, 234; R.P. Chandrasekhara, P. Gautier, The ITLOs: law, practice and procedure (Elgar, 2018), 138; J. Harrison, Saving the oceans through law (OUP, 2017), 24-25; Responsibilities and Obligations of States Sponsoring Persons and Entities with Respect to Activities in the Area, Advisory Opinion of 1 February 2011, ITLOS Case No. 17, ITLOS Reports 2011, p. 10, at p. 59, para. 180. ARSIWA Commentary, Art. 48, para. 10. It is implausible, however, to argue that each and every environmental provision of the Convention is of customary - let alone erga omnes - status. Churchill and Lowe (The Law of the Sea (1999)) have further identified Articles 210(5), 221, 236 as being reflective of custom, whereas they find doubtful that provisions relating to coastal and port state jurisdiction in respect of ships are of customary nature due to limited and divergent practice, 352-353; also Y. Tanaka, The International Law of the Sea (CUP, 2012), 264, 266.

53 H.S. Bang, "Port State Jurisdiction and Article 218 of the UN Convention on the Law of the Sea", 40 J. Mar. L. \& Com. (2009), 291; see D. König, "The Enforcement of the International Law of the Sea by Coastal and Port States", 62 ZaöRV (2002), 1.

54 Tams (2011), supra note 2, 398.

55 All States may have a legal interest against the flag State if there is a violation of Article 192 in conjunction with Article 94 LOsC. 
covering all aspects of the ocean. ${ }^{56}$ In the Southern Bluefin Tuna case, the ITLOS declared that the conservation stocks was a community interest and that the parties should act "with prudence and caution" to prevent serious harm to the stock. ${ }^{57}$ Conservation is required to take place both in areas under national jurisdiction by the coastal state and in areas beyond national jurisdiction $(\mathrm{ABNJ}){ }^{58}$ In areas under national jurisdiction, there may not be a directly injured or specially affected state to invoke the responsibility of the coastal state. The conservation framework does not establish separable bilateral relations between parties, and hence, it falls upon third states to invoke the responsibility under Article 48 ARs IWA. ${ }^{59}$ Regarding conservation taking place in $\mathrm{ABNJ}$, all states have the freedom to fish on the HS, subject to limitations prescribed in Articles $87(1)$ and 116 LOSC. In ABNJ all states are under a duty to co-operate with other states in taking the conservation measures concerning the living resources of the HS making use of international fishery commissions or regional fisheries management organizations (RFMOs) ${ }^{60}$ Non-members of RFMOs are expected to comply with the measures, or to refrain from fishing. States may invoke the responsibility of other states that do not abide by their conservational obligations and flag states are under the obligation to take the necessary measures "to ensure" that vessels flying their flag are not engaged in illegal, unreported, and unregulated (IUU) fishing activities in the HS. ${ }^{61}$

Finally, the principle of the "common heritage of [hu]mankind" forms the backbone of legal regimes that regulate global commons. ${ }^{62}$ In the LOSC the

$5^{6}$ Southern Bluefin Tuna Cases (New Zealand v. Japan; Australia v. Japan) (Provisional Measures) ITLOS Order, 27 August 1999, para. 70.

57 Ibid., 77 .

$5^{8}$ Case No. 21 Fisheries Advisory Opinion (2015); C. Goodman, "Rights, Obligations, Prohibitions: A Practical Guide to Understanding Judicial Decisions on Coastal State Jurisdiction over Living Resources in the Exclusive Economic Zone", 32 I.J.M.C.L. (2017), 1.

59 See R. Barnes, "The Convention on the Law of the Sea: An Effective Framework for Domestic Fisheries Conservation?", in D. Freestone et al. (eds.), The Law of the Sea: Progress and Prospects (2006).

6o Article 116 LOSC and Article 1191995 Fish Stocks Agreement (FSA).

61 Barnes in Freestone et al. (2006), supra note 59, 239.

62 Joyner, Martell (1996): "[a] global commons is an area beyond the limits of national jurisdiction to which all peoples have free and open access. Such commons are generally meant to include the oceans, outer space, and Antarctica". See generally, N. Matz-Luck, "The Concept of the Common Heritage of Mankind: Its Viability as a Management Tool for Deep Sea Genetic Resources", in E. Molenaar and A. Elferink (eds.), The International Legal Regime of Areas beyond National Jurisdiction: Current and Future Developments (Brill, 2010), 61-75; C. Redgwell, "Protecting Natural Heritage and its Transmission to Future Generations", in A. Yusuf (ed.), Normative Action in Education, Science and Culture 
principle is found in provisions regulating the Area (Article 136) which is administered by the International Seabed Authority (ISA). ${ }^{63}$ Article 311(6) attributes to Article 136 a status similar to jus cogens, whereas Article 137 is phrased as an obligation of all states and not only of the state parties to the Convention. ${ }^{64}$ Consequently, the legal regime for the Area and its resources seeks to promote the benefit of humankind as a whole and, thus, the rules governing the Area are not based on mutual advantages between states. In that sense, these LOSC provisions can be considered as operating erga omnes. ${ }^{65}$ The Area is preserved for [hu]mankind and all states have a legal interest in its protection. Article 76 LOSC grants coastal states the right to determine the outer limits of their continental shelves. Where such determination allegedly infringes the rights of states with adjacent or opposite coasts, these states can be perceived specially affected and initiate a claim in their own right. If, however, a state is not adjacent or opposite, it could also still bring a claim of a collective interest nature directed at enforcing obligations erga omnes. Any state party could claim to act on behalf of the international community on the basis that the determination of the outer continental shelf by a coastal state unjustifiably reduces its scope. ${ }^{66}$ Of course, limiting the scope of the Area inevitably also means limiting the scope of potential economic activity by states and, thus, they may as well be acting in their own interest when defending the scope of the Area in the interest of the international community as a whole.

(Essays in Commemoration of the 6oth Anniversary of UNESCO) (UNESCO, 2007), Doc. WHC.05/2, para. 77 .

63 Losc Preamble and Articles 136, 157; S. Ranganathan, "The Law of the Sea and Natural Resources", in E. Benvenisti, G. Nolte, Community Interests across International Law (ouP, 2018); Crawford (2011), supra note 35, 238; R. Wolfrum, "Identifying Community Interests in International Law: Common Spaces and Beyond", in E. Benvenisti, G. Nolte (2018).

64 R. Wolfrum, "Common Heritage of Mankind", Max Planck Encyclopedia P.I.L. (2009), stating that the prohibition of occupation and appropriation has been given a legal status the effect of which is similar to that of ius cogens.

65 R. Wolfrum, "Enforcing Community Interests through International Dispute Settlement: Reality or Utopia", in U. Fastenrath, R. Geiger, D.E. Khan, A. Paulus, S. Shorlemer and C. Vedder (eds.), From Bilateralism to Community Interests: Essays in Honour of Bruno Simma (OuP, 2011), 1136; T. Scovazzi, "Mining, Protection of the Environment, Scientific Research and Bioprospecting: Some Consideration on the Role of the International Seabed Authority", 19 I.J.M.C.L. (2004), 383, 398; Cf. de Wet, "Invoking Obligations Erga Omnes in the Twenty-first Century: Progressive Developments since Barcelona Traction", 37 S.A.Y.I.L. (2013), $1,4$.

66 R. Wolfrum (2018) proposes the request of an advisory opinion as a solution. 


\section{Invocation of Obligations erga omnes under the Losc's Dispute Settlement System}

One of the criticisms leveled against Article 48 ARsiWA was that it would "open the flood gates" of litigation. ${ }^{67}$ Today, such a concern appears unfounded. First, it must be clarified that the erga omnes nature of a rule leaves the consensual character of the judicial proceedings, expressed in the legal concept of "jurisdiction" of the Court, unaffected. In East Timor, the ICJ rejected the argument that erga omnes obligations could be sufficient to override state consent to jurisdiction. The same position was taken by the Court in the Genocide case, where it refrained from extending its jurisdiction on the basis of erga omnes qualification. ${ }^{68}$ Indeed, legal standing is a matter of "admissibility" of the application, which is readily distinct and independent from the question of "jurisdiction" of the Court. If either is missing, the result is that the application will not be adjudicated. Secondly, and more importantly for our inquiry, states readily engage in litigation when their individual interests are at stake, but rarely make use of judicial and arbitral proceedings acting on behalf of the international community. This is partly due to procedural hurdles that the bilateral structure of adjudication presents and partly due to the stance that states themselves have adopted towards international adjudication, seeing it as a means to vindicate individual interests.

The present section examines the enforcement of obligations erga omnes embodied in the LOSC through the DSs's (Part Xv) contentious jurisdiction. States give their consent to compulsory procedures entailing binding decisions from the moment they become parties to the Convention (quasi-compulsory jurisdiction). ${ }^{69}$

67 ILC, 4th Report on State Responsibility (53rd session), A/CN.4/517 (2001), paras. 39 and 41 (comments from Japan and France); see also ILC, 3rd Report on State Responsibility (52nd session), A/CN.4/507 (2000), paras. 141-143 (comments from Italy); see also A/ CN.4/504, para. 62 (Venezuela); A/CN.4/488 97, 99 (Austria and the United States).

68 East Timor (1995), para. 29; similarly, Armed Activities (Democratic Republic of the Congo v. Rwanda) (2002) (Provisional Measures), para. 71; Genocide case (Bosnia and Herzegovina v. Serbia and Montenegro) (2007), para. 147. The Court reiterated its position in CERD case (Georgia v. Russian Federation) (Preliminary Objections) (2011). Georgia had submitted only treaty-based jurisdictional claims showing that states have taken their steer from the Court's consistent jurisprudence on the issue. Cf. Belgium v. Senegal (2012), Diss. Op. of Judge Cançado Trindade, paras. 23, 71.

69 States however do not "contract out" of general international law erga omnes enforcement rights by becoming parties to the Convention (Articles 280-282 LOSC), T. Treves, "A System for Law of the Sea Dispute Settlement", in Freestone et al. (2006), 428. 
At the time of its adoption, Part XV of the Convention was considered one of the most far-reaching and detailed systems of dispute settlement found in an international multilateral treaty, being distinctive for its user-friendly, diverse, and flexible formula that included both traditional and innovative elements. ${ }^{70}$ Article 297 LOSC stipulates that states parties shall settle any dispute between them concerning the interpretation or application of the Convention.

However, it is argued that, despite the existence of a sophisticated dispute settlement system, the latter presents considerable challenges with respect to the enforcement of communitarian norms. This is because (1) certain types of disputes that could potentially involve erga omnes claims are excluded from the application of Part Xv; and (2) the adversarial and bilateral compromissory clause and the traditional ways of "multilateralizing" proceedings, such as intervention, do not allow for proper invocation of responsibility for breaches of communitarian norms. These inherent limitations to the system lead states wishing to present erga omnes claims to try and find ways to fit them into existing bases of jurisdiction and point out their own interest, rather than, or alongside, the interest of the international community. ${ }^{71}$

\subsection{Ratione materiae Limitations}

The resort to adjudication or arbitration is limited by Section 3 of Part XV, which explicitly (a) excludes the applicability of compulsory procedures for certain disputes and (b) provides states with the option of excluding certain other categories of disputes. Exclusive Economic Zone (EEZ) fisheries disputes were the first to be removed from compulsory procedures and be submitted to conciliation (Article 297(3) LOSC). ${ }^{72}$ The use of conciliation is obligatory, but the

$70 \quad$ Inter alia, D. Anderson, "The International Tribunal for the Law of the Sea", in M.D. Evans (ed.), Remedies in International Law: The Institutional Dilemma (OuP, 1998), 71; T. Treves, "Introductory Note", 1 Global Community Yrbk I.L.J. (2001), 269; E. Brown, "Dispute Settlement and the Law of the Sea: The UN Convention Regime", 21 Marine Policy (1997), 17; J. Collier, V. Lowe, The Settlement of Disputes in International Law (ou P, 1999), Chapter 4; N. Klein, Dispute Settlement in the UNCLOS (CUP, 2005); L. Sohn, "Settlement of Disputes Arising out of the Law of the Sea Convention", 12 San Diego L. Rev. (1975), 495; A. Boyle, "Dispute Settlement and the Law of the Sea Convention: Problems of Fragmentation and Jurisdiction", 46 I.C.L.Q. (1997), 37, 38-39; R. Churchill, "Some Reflections on the Operation of the Dispute Settlement System of the UN Convention on the Law of the Sea During its First Decade", in Freestone et al. (eds.) (2006), 389.

71 F.O. Vicuna, "International Claims", Max Planck Encyclopedia P.I.L. (2010), noting that adjudication of erga omnes obligations is often associated with the difficulties of acceptance of actio popularis in international law.

72 A. Adede, "Environmental Disputes under the Law of the Sea Convention", 7 Envt'l Pol'y \& L. (1981), 63,66 . 
coastal state's exercise of its discretion cannot be questioned, and the commission's report is not binding on the parties. The exception covers the setting of the total allowable catch, the determination of harvesting capacity, the surplus allocation, and the conservation and management responsibilities. ${ }^{73}$ Further, Article 298(1)(b) provides that disputes concerning law enforcement activities in regard to the exercise of sovereign rights or jurisdiction excluded from the jurisdiction of a court or tribunal under Article 297(3) may be excluded from the jurisdiction of a court or tribunal. ${ }^{74}$

It is apparent that there is an absence of effective dispute settlement procedures vis-à-vis EEZ conservation and management issues. Coastal states are "immune" when it comes to domestic fisheries practices and, once a coastal state has adopted measures for resource exploitation in its EEZ, there is no third-party decision-making process capable of enforcing any conservation duties on that state. ${ }^{75}$

Nevertheless, no retreat from the compulsory procedure has been established for the protection of the marine environment. ${ }^{76}$ The absence of environmental disputes from Section 3 exceptions distinguishes them from the treatment of fisheries under Part XV. As favourable as this framework for environmental disputes may seem, it is often challenged by the multi-faceted nature of such cases. The protection and preservation of the marine environment and conservation of living resources are intertwined, which risks certain marine environmental disputes falling outside the scope of compulsory dispute settlement under the limitation of Article 297. However, tribunals are able to separate the different layers of such disputes and have rejected narrow interpretations of Article 297(1)(c), which subjects environmental disputes to the DSs. ${ }^{77}$

73 Chagos MPA Arbitration, Award (2015), paras. 300-305; Cf. South China Sea Arbitration, Final Award (2016), PCA Case No. 2013-19, available at http://www.pcacases.com/web/ view/7 (hereinafter: scs Arbitration Final Award), para. 682; N. Klein, "The Vicissitudes of Dispute Settlement under the Law of the Sea Convention", 32 I.J.M.C.L. (2017), 332, 350-351; A. Ntovas, "Interpreting the dispute settlement limitation on fisheries after the Chagos MPA Arbitration", in S. Minas et al. (eds.), Stress Testing the Law of the Sea:Dispute Resolution, Disasters \& Emerging Challenges (Brill, 2018).

74 Arctic Sunrise Arbitration, Award on Jurisdiction (2014), paras. 72-77; scs Arbitration, Award on Jurisdiction and Admissibility (2015), paras. 390-396.

75 A. Elferink, "Reviewing the Implementation of the LOSC: The Role of the UN GA and the Meeting of states parties", in A. Elferink, D. Rothwell, Oceans Management in the 21st Century: Institutional Frameworks and Responses (Martinus Nijhoff, 2004), 295.

$7^{6}$ Article 297(1) LosC.

77 See Chagos MPA Arbitration, Award (2015), Diss. and Concurring Op. of Arbitrators Kateka and Wolfrum, para. $5^{6}$. 
It goes without saying that Section 3 only prevents the unilateral reference of a dispute to the DSS and is without prejudice to the parties' right to consensually submit disputes to whichever forum they choose (Article 299). Thus, the judicial enforcement of obligations erga omnes excluded from Part XV depends on the willingness of states to bring cases for contentious adjudication. ${ }^{78}$

\subsection{Multilateralization?}

Beyond the ratione materiae limitations, the mechanisms provided for in the DSs are not particularly conducive to disputes that involve communitarian claims because the latter would often require multiparty proceedings. As Crawford has suggested, "the development of a procedural framework permitting invocation by more than one member of the international community in multiparty proceedings instead of the traditional approach of joining related proceedings would be rather advantageous for the invocation of responsibility for breaches of communitarian norms." ${ }^{\prime 79}$ Intervention is indeed a way to "multilateralize" a dispute, or in Tanaka's words "to mitigate bilateralism in international adjudication". ${ }^{80}$ Both the ICJ and the ITLOS allow states which consider that they have a legal interest in the outcome of a case to request permission to intervene. ${ }^{81}$ Article 62 ICJ Statute could be interpreted to allow intervention in the public interest, but the Court is rather reluctant to accept interventions of this kind possibly in an effort to prevent actio popularis masked as intervention. ${ }^{82}$ Of course, in cases involving obligations erga omnes the

78 T. Stephens, "The Limits of International Adjudication in International Environmental Law: Another Perspective on the SBT Case", 19 I.J.M.C.L. (2004), 177, 195.

79 J. Crawford, "Responsibility for Breaches of Communitarian Norms", in State Responsibility: The General Part (CUP, 2013), 376; see also R. Wolfrum (2018): "[ $t$ ] he respective procedural rules do not provide adequate ways for members of the international community to intervene, and the practice concerning submissions of $\mathrm{NGO}$ s is restrictive even with respect to advisory opinions."

8o Y. Tanaka (2021), supra note $36,28$.

81 Article 62 ICJ Statute and Article 31 ITLOs Statute. See R. Wolfrum, "Intervention in the Proceedings before the ICJ and the ITLOs", in V. Gotz (1999), 438. S. Oda, "Intervention in the ICJ: Articles 62, 63 of the Statute", in R. Bernhardt et al. (eds.), Völkerrecht als Rechtsordnung Internationale Gerichtsbarkeit Menschenrechte (Springer, 1983), 629648; C. Chinkin, "Third Party Intervention before the ICJ", 80 A.J.I.L. (1986), 495-531; C. Chinkin, "Article 62" and "Article 63", in A. Zimmermann, C. Tomuschat, K. OellersFrahm (eds.), The Statute of the ICJ: A Commentary (oup, 2006), 1331-1368, 1369-1392; S. Rosenne, The Law and Practice of the International Court of Justice (Nijhoff, 2006).

82 Continental Shelf (Tunisia/Libya) case (Application by Malta for Permission to Intervene) (1981). The concept of actio popularis, although not a terminus technicus in international law, denotes action taken for the protection of a "public" interest, i.e., action based on obligations erga omnes (partes). As Gattini explains, the distinction between erga omnes 
protection of interests owed to the international community as a whole should be a sufficient objective for the purpose of intervention, although neither the ICJ nor the ITLOS have addressed the question so far. ${ }^{83}$ Intervention could then be used for safeguarding the overarching objectives of the Convention, but its limited scope makes it a weak mechanism for this purpose. ${ }^{84}$

Similarly, the practice of amici curiae might bring useful information to courts or tribunals regarding obligations owed to the international community, although their reliability and objectivity cannot be guaranteed, as they are usually private actors, such as individuals and NGO ${ }^{85}$ In any case, obligations erga omnes are owed to the international community of states as a whole and other actors acting as amici curiae can have only a very minor role in their enforcement through dispute settlement.

\subsection{Shoehorning Obligations erga omnes under Part XV}

Despite the above limitations, Part XV typically leaves considerable space for bringing claims in the public interest. Article 288 does not require states to solely defend their individual interests when submitting cases to the DSs and

and erga omnes partes in that respect is artificial: "[...] it would not make a difference whether the public interest is one which appertains to the community as a whole, $[\ldots]$, or whether it follows from the concern of the community with regard to some specific issues, e.g., the protection of human rights or minority rights." (A. Gattini, "Actio Popularis", Max Planck Encyclopedia I. Pro. (2019)).

83 P. Palchetti, "Opening the ICJ to Third states: Intervention and Beyond", 6 Max Planck Yrbk U.N.L. (2002), 139, 155-158, 179; S. Murphy, "Amplifying the World Court's Jurisdiction through Counter-Claims and Third-Party Intervention”, 33 G. Wash. Int'l L. Rev. (2000), $5,26$.

84 R. Wolfrum, "Intervention in proceedings before international courts and tribunals: To what extent may interventions serve the pursuance of community interests?", in N. Boschiero et al. (eds.), International courts and the development of international law: Essays in honour of Tullio Treves (2013), 222; M. Forteau, "Third Party Intervention as a Possible Means to Bridge the Gap Between the Bilateral Nature of Annex VII Arbitration and the Multilateral Nature of UNCLOs", in The Rule of Law in the Seas of Asia: Navigational Chart for Peace and Stability (International Symposium on the Law of the Sea, 31 March 2015).

85 J. Razzaque, "Changing Role of Friends of the Court in the International Courts and Tribunals", 1 N.S.A.I.L. (2001), 169; L. Boisson de Chazournes, "Transparency and Amicus Curiae Briefs", 5 J.W.I.T. (2004), 333-336; M. Matsushita, "Transparency, Amicus Curiae Briefs and Third Party Rights", 5 J.W.I.T. (2004), 329-332; D. Shelton, "The Participation of Nongovernmental Organizations in International Judicial Proceedings", 88 A.J.I.L. (1994), 611-642; P. Gautier, "NGO s and Law of the Sea Disputes", in Treves et al. (eds.), 238. See J. Razzaque, "Changing role of friends of the court in the International Courts and Tribunals", 1 Non-state Actors and International Law (2001), 169, 188-195. 
explicitly prescribes that the adjudicatory bodies have jurisdiction "over any dispute concerning the interpretation and application" of the Convention.

The Dss, however, does not possess any differentiated procedural rules for public interest disputes. ${ }^{86}$ All disputes that arise with respect to the interpretation or application of the Convention are heard and decided as traditional contentious cases (state v. state) and hence, when erga omnes claims are brought under the DSs, must be framed so as to fit into its bilateralized compromissory clause. Nevertheless, bilateralization attempts are not always successful, leading states to questionably package - or rather shoehorn - their claims into the confines of the compromissory clause, while in some instances applicants are even using these broader provisions of the LOSC with no real intention of enforcement but as a pretext in order to activate the Convention's basis of jurisdiction. ${ }^{87}$ It is thus questionable whether the DSs is appropriate to resolve disputes of a multilateral nature that are purely about the broader provisions of the LOSC.

There are of course examples of obligations erga omnes being invoked in disputes where the injury of the applicant was direct and the bilateralization of the obligation posed no remarkable challenges. For instance, freedom of navigation was invoked by the Netherlands in the Arctic Sunrise Arbitration along the lines of a bilateralized dispute, i.e., the blocking of navigational rights of the Arctic Sunrise vessel (flagged to the Netherlands) by Russia. The Netherlands protested against the arrest of the vessel and started arbitral proceedings against Russia claiming standing on various grounds, the last of which was based on breaches of obligations erga omnes (partes). ${ }^{88}$ The Tribunal concluded that the Netherlands already had standing to invoke the international responsibility of Russia for alleged breaches of obligations owed directly to the Netherlands under the Convention and, hence, it was not necessary to consider whether the Netherlands had standing as a result of the erga omnes (partes) character of the obligation. In this case the Netherlands was a directly injured state and the bilateralization of the freedom of navigation was

86 Similar concerns in Wolfrum (2018) and Benzing (2006).

87 Extensive analysis in A. Tzanakopoulos, "Resolving Disputes over the South China Sea under the Compulsory Dispute Settlement System of the UN Convention on the Law of the Sea", 14 Soochow L. Journal (2017), 119; Boyle (1997), supra note 70, 44-45.

88 See Submission of dispute to arbitration "Arctic Sunrise"; The Kingdom of the Netherlands v. The Russian Federation (2013), paras. 1, 4; Arctic Sunrise Award, paras. 121-128, 133; The 'Arctic Sunrise' Case (Prompt Release), Order 22 November 2013, ITLos Case No. 22, para. 105. 
straightforward. ${ }^{89}$ What has been called to attention was the individual direct injury of the state rather than the interest of the international community. The following two examples, however, illustrate the hurdles that bilateralization attempts may cause in the function of the system and consequently in the enforcement of obligations erga omnes.

\subsubsection{The Chagos MPA Arbitration}

The Chagos MPA case was in part about the interpretation of the term "coastal state" and in part about the broader objectives of preventing, reducing, and controlling pollution of the marine environment and of conserving, managing, and exploiting fish stocks in order to protect marine living resources. In 2010 Mauritius challenged the legality of the establishment by the United Kingdom of a Marine Protected Area (MPA) in the 200-nautical-mile zone around Chagos Island. The Annex VII Tribunal was asked to find that the United Kingdom was not entitled to declare an "MPA" or other maritime zones because it is not the "coastal state" within the meaning of the Convention, and also that the United Kingdom's purported MPA was incompatible with the substantive and procedural obligations of the United Kingdom under the Convention and the FSA. ${ }^{90}$

By formulating its claim partly as a "who is the coastal state" dispute, Mauritius attempted to present its struggle to reclaim sovereignty over the islands as a case about marine environment and conservation, trying to attract the Tribunal's jurisdiction. ${ }^{91}$ The United Kingdom's line of defence against Mauritius's first submission was indeed that in reality the claim concerned sovereignty over the Chagos Archipelago and, therefore, did not concern the interpretation and application of the LOsc. The Tribunal agreed that the determination of whether the United Kingdom was the "coastal state" with respect to the islands would have required it to determine "sovereignty over the Chagos Archipelago." As the Tribunal emphasized, " $[t]$ he Parties' differing views on the 'coastal state' for the purposes of the Convention are simply one aspect of this larger dispute" and, while minor sovereignty questions could be considered if they were ancillary to a main dispute concerning the interpretation and

89 Similarly, Sвт case (Australia and New Zealand v. Japan), Award on Jurisdiction and Admissibility (2000), 39 I.L.M. 1359; The MOX Plant Case (Ireland v. United Kingdom) (Order No. 3) (24 June 2003).

90 Chagos MPA Arbitration, Award (2015), para. 158.

91 Chagos MPA Arbitration, Award (2015), paras. 176 and 212; Boyle notes that, in practice, everything turns around not what each case involves but how the issues are formulated (Boyle (1997), supra note 70, 38); S. Talmon, "The Chagos Marine Protected Area Arbitration: Expansion of the Jurisdiction of UnCLOS Part XV Courts and Tribunals", 65 I.C.L.Q. (2016), 927, 928. 
application of the Convention, this could not be so for long-standing disputes over territorial sovereignty as such. ${ }^{92}$ Regarding the environmental claims of Mauritius, the Tribunal concluded that it could separate the multi-layered dispute and found jurisdiction to consider claims regarding the establishment of the MPA. ${ }^{93}$ As to how the breaches on the part of the United Kingdom would be remedied, the Tribunal left the issue of the protection of the marine environment to bilateral negotiations. ${ }^{94}$

Talmon views the Chagos MPA Arbitration as an excellent example of the creative or strategic use of the LOSC compulsory dispute settlement mechanism in order to gain a ruling on issues that have nothing to do with the law of the sea or the protection of the marine environment. Except for the underlying motivations, Mauritius had to frame its action in such a way as to point out its own interest in order for the dispute to fit into the bilateralizable clause of the Convention. The real questions of the dispute were actually brought before the ICJ as a request for an advisory opinion by the General Assembly. The ICJ in its 2019 Advisory Opinion affirmed the erga omnes character of the obligation to self-determination and called for collective and cooperative action of all states to complete the decolonisation of Mauritius. ${ }^{95}$

\subsubsection{South China Sea (scs) Arbitration}

Part of the multiple claims the Philippines submitted in 2013 in arbitration proceedings against China were related to China's alleged breaches of environmental and fisheries obligations under the Losc. ${ }^{96}$ Paul Reichler, on behalf of the Philippines, stated that "this is really the first case to go to judgment over environmental provisions of the Law of the Sea." ${ }^{97}$ China refused to

92 Chagos MPA Arbitration, Award (2015), paras. 211-212; S. Talmon (2016), supra note 91, 927, 928.

93 Chagos MPA Arbitration, Award (2015), para. 304.

94 Ibid., paras. 540-544.

95 Legal Consequences of the Separation of the Chagos Archipelago from Mauritius in 1965, Advisory Opinion, 25 February 2019, ICJ Reports 2019, paras. 180-183; see also Dispute concerning delimitation of the maritime boundary between Mauritius and Maldives in the Indian Ocean (Mauritius/Maldives), ITLOs, Order (3 February 2021).

96 Ibid., Submissions No. 11 and 12(B). See Y. Tanaka, "The South China Sea Arbitration: Environmental Obligations under the Law of the Sea Convention" (case note), R.E.C.I.E.L. (2018), 1, 2. sCs Final Award, para. 9o6, found that with respect to environmental claims China had indeed breached obligations enshrined in Articles 192, 194(1)(5), 197, 123 and 206 of the LOSC.

97 S. Leavenworth, "In South China Sea case, ruling on environment hailed as precedent" (20 July 2016), <http://www.csmonitor.com/World/Asia-Pacific/2016/o72o/In-South -China-Sea-case-ruling-on-environment-hailed-as-precedent >; P.S. Reichler, "The Rule of Law and the Path to a Just and Lasting Peace in the scs", 1(2) Japan Review (2017), 6. 
participate in the arbitral proceedings, all the while making arguments similar to the ones submitted by the United Kingdom in the Chagos MPA Arbitration. Extrajudicially, China argued that the Philippines brought a case that fundamentally concerned a question of territorial sovereignty, not actually caring about the marine environment. ${ }^{98}$

Indeed, the case was not singularly on environmental issues. The main claims brought by the Philippines related to maritime features and the [maritime zone] entitlements they generate. As was the case in the Chagos MPA Arbitration, the Tribunal was called upon to determine "the real issue in the case and to identify the object of the claim." ${ }^{\prime 99}$ One would expect that the Tribunal would similarly find that this was a dispute about sovereignty over maritime features in the scs and that any determination of the status of maritime features would have the effect of prejudging Chinese claims to sovereignty, but also claims of third states, possibly creating Monetary Gold issues. ${ }^{100}$ Nevertheless, the Tribunal found that it had jurisdiction with respect to those claims and held that its consideration did not require conducting a sovereignty determination first, departing from the reasoning of the Tribunal in the Chagos MPA Arbitration. ${ }^{101}$

The situation in the scs is more complicated than in the Mauritius v. United Kingdom case, in the sense that the dispute evidently concerns many more states than the two parties to the arbitration. There are mainly two reasons for that. Firstly, the scs includes highly productive fisheries and extensive coral reef ecosystems which are closely connected and, therefore, the impact of environmental harm occurring in one ecosystem may affect the viability of ecosystems elsewhere. ${ }^{102}$ The Philippines submitted that China's actions have

98 scs Arbitration Final Award, paras. 11, 13, 96o, 992-993, 956-966, 1203(12) and (13). On the basis of expert reports, the Tribunal found that, through its construction activities, China had breached its obligations under Articles 192, 194(1) and (5) of the Losc (scs Final Award, para. 983).

99 scs Arbitration Jurisdiction Award, para. 150.

100 Monetary Gold Removed from Rome in 1943 (Italy v. France, United Kingdom and United States) (Preliminary Question) (1954). Malaysia indeed claimed so: SCS Final Award, paras. 79, 635; Chagos MPA Arbitration, Award (2015), para. 215; A. Tzanakopoulos (2017), 7, 8-9, 13; S. Talmon, "The South China Sea Arbitration: Observations on the Award on Jurisdiction and Admissibility", ${ }_{5}$ Chinese J.I.L. (2016), paras. 52, 95.

101 scs Arbitration Final Award, para. 153.

102 scs Arbitration Final Award, para. 823; scs Final Award, para. 85; M. Lim, N. Liu, "Condominium Arrangements as a Legal Mechanism for the Conservation of the South China Sea Large Marine Ecosystem", 2 Asia-Pacific Journal of Ocean Law and Policy (2017), 52; D. Rosenberg, "Fisheries Management in the South China Sea", in S. Bateman, R. Emmers (eds.), Security and International Politics in the South China Sea: Towards a Cooperative Management Regime (Routledge, 2009), 62. 
damaged the diverse and fragile ecosystem of the scs and that they pose a threat not only to the marine ecosystems as such but to all of the states which border them. ${ }^{103}$ Moreover, the marine environment of the minimal Hs pockets and the Area in SCS might be equally affected and, in this sense, the disputes in the SCS area concern common interests of the international community as a whole. ${ }^{104}$ Secondly, the dispute brought before the Tribunal was essentially multilateral. There are several states that border and have interests in the scs, i.e., China (mainland and Taiwan), Brunei, Malaysia, Vietnam, the Philippines and Indonesia, and perhaps even Singapore and the Gulf of Thailand states. Even if this was a typical case on sovereignty before the ICJ, its bilateralization would be equally problematic, given that more than two states have made competing sovereignty claims over the disputed maritime features. ${ }^{105}$ What is more, due to its geographical position, the scs is a globally important area with regard to international shipping and trade, and leading economies like the United States, India, Japan, Korea, and Australia rely heavily on it as a key trade route. ${ }^{106}$ Freedom of navigation for merchant shipping is of particular significance to those states, so that any conflict in the area would adversely affect their interests. It is not surprising that, in the arbitral procedure, Australia, Indonesia, Japan, Malaysia, Singapore, Thailand and Vietnam participated as observer states, while the United States and the United Kingdom communicated through notes verbales to the Tribunal that they have keen interests in the proceedings. ${ }^{107}$ The Philippines itself claimed before the Tribunal that the arbitration will benefit the rest of the international community as well and "will help ensure peace, security, stability and freedom of navigation and overflight in the scs."108

Disputes like this may not be fit for resolution in the context of a bilateral, adversarial proceeding between only two of the many disputants. ${ }^{109}$ China ignored the award, the sovereignty dispute continues and is being detrimental to all coastal states as well as to the international economic interests of

\footnotetext{
103 Ibid., para. 891.

104 Tanaka (2018), supra note 96, 1-2.

105 Z. Gao, B.B. Jia, "The Nine-Dash Line in the South China Sea: History, Status and Implications", 107 A.J.I.L. (2013), 98, 110-113.

106 N. Liu, M.S. Karim, "South China Sea After the Philippines v. China Arbitration, Conflict and Cooperation in Troubled Waters", 2 Asia-Pacific Journal of Ocean Law and Policy (2017), 1, 3-7.

107 United States, para. 65. The Tribunal however decided "only interested States parties to UNCLOS will be admitted as observers" and thus could not accede to the U.S. request; United Kingdom, para. 67.

108 scs Final Award, para 74.

109 Tzanakopoulos (2017), 14.
} 
non-claimant states, while the damage inflicted on the environment cannot be undone and no remedies were provided for in the award. ${ }^{110}$ It is readily apparent that widespread and deep-rooted problems affecting the interests of the international community are perhaps better addressed through other avenues - such as the development of treaties, soft law instruments or collective action by all states -, and that adjudication of a single case will not solve them.111

\section{$5 \quad$ Conclusion and Alternatives for Enforcement}

At the time of its conclusion, the LOSC DSs was praised for its innovative character. Even so, in practice the framework proves to be unsuitable for the demands of the Convention's overarching community aspect. The enforcement of communitarian norms fits ill with bilateral structures that are designed to assume bilateralizable obligations between two states, and even when brought under the Convention's mechanism, claims based on obligations erga omnes are never states' sole plank, rather they are always prayed in aid alongside and in the context of bilateralizable disputes. ${ }^{112}$ It is concluded that the LOSC DSS is not attuned to solve disputes involving erga omnes claims.

Advisory jurisdiction has been suggested as a better suited alternative to safeguard wider objectives reflected in the Convention. Indeed, the nonbinding character of advisory opinions and the flexible requirements for their request may be more effective for certain types of disputes. ${ }^{113}$ Crawford observes that states tend to request advisory opinions regarding questions of interpretation and application of communitarian norms, especially through

110 R. Beckman et al. (eds.), Beyond Territorial Disputes in the South China Sea: Legal Frameworks for the Joint Development of Hydrocarbon Resources (Edward Elgar, 2013).

111 Churchill (2006), supra note 70; Boyle, Freestone, Redgwell, 236: "[w] here the harm is to common spaces, [...], there is less likelihood that a willing plaintiff will appear, or press claims to the full."

112 Sep. Op. Judge Tomka, Marshall Islands v. United Kingdom case, ICJ Reports 2016, paras. 38-39; R. Wolfrum, "Identifying Community Interests in International Law: Common Spaces and Beyond", in E. Benvenisti, G. Nolte, Community Interests across International Law (OUP, 2018), 33 .

113 D. Kim, "Advisory Proceedings before the International Tribunal for the Law of the Sea as an Alternative Procedure to Supplement the Dispute-Settlement Mechanism under Part XV of the United Nations Convention on the Law of the Sea", 7(1) Issues in Legal Scholarship (2010), 1539 . 
IO s. ${ }^{114}$ For example, in the ITLOs Fisheries Advisory Opinion ${ }^{115}$ the request was made by the Sub-Regional Fisheries Commission for the problem of IUU fishing in the EEZ of the members of the Commission. The proceedings allowed the participation of numerous actors. Written statements were submitted by twenty-two states parties to the LOSC, the SRFC and six other organisations. In the oral hearings, statements were made by the SRFC, ten states parties to the LOSC and two IOs. The advisory opinion shed light on the obligation of flag states to ensure that their fishing vessels are not involved in activities that undermine flag states' responsibilities under the Convention in respect of the conservation of living resources and the obligation to protect and preserve the marine environment. ${ }^{116}$ The request for this advisory opinion seems to have worked as a surrogate of what would have otherwise been a complex dispute involving erga omnes claims that would have been necessarily reduced in bilateral relations between states if it was to be resolved in the contentious jurisdiction of the Convention. ${ }^{117}$ Nevertheless, non-contentious proceedings remain outside a strict enforcement context since opinions rendered are not binding upon states. ${ }^{118}$

Further, institutional compliance mechanisms akin to those found in multilateral environmental agreements could have been more apposite for communitarian claims. ${ }^{119}$ Compliance procedures do not require the crystallization of a dispute between complaining and defending states, thus, they remove the need for a bilateralized relationship and their focus lays on how a state's conduct which is not in compliance with an obligation can be brought back to compliance. ${ }^{120}$ Knowing that states were willing to accept quasicompulsory dispute settlement in the Convention, it is odd that they did not

114 Crawford (2011), supra note 35, 237-238, referring to Reservations to the Convention on Genocide (Advisory Opinion) (1951) ICJ Reports 15, 23, where the "[c]ourt underlined the communitarian character of the Genocide Convention"; other examples are the Wall, Nuclear Weapons and Namibia Advisory Opinions.

115 Case No. 21 Request for an Advisory Opinion submitted by the Sub-Regional Fisheries Commission (SRFC) (2014).

116 Ibid., paras. $118-136$.

117 Similarly see the Sea-Bed Advisory Opinion, No. 17 Responsibilities and obligations of States sponsoring persons and entities with respect to activities in the Area 2010.

118 However, they might have an authoritative weight as to the content of international obligations, as per the Fisheries Advisory Opinion and/or remarkable legal effects to other proceedings, as per the Chagos Advisory Opinion.

119 M. Bothe, "The Evaluation of Enforcement Mechanisms in International Environmental Law", in R. Wolfrum (ed.), Enforcing Environmental Standards: Economic Mechanisms as Viable Means (Springer, 1996).

120 Inter alia inspection, verification, and investigation systems in the Non-Proliferation Treaty, the Chemical Weapons Convention, the Nuclear Test-Ban Treaty and the 
include a compliance body as well. ${ }^{121}$ Given the cafeteria approach the drafters adopted, they could have simply added compliance to the "menu". Probably at the time of its conclusion, states were focused on the bilateralizable disputes that were likely to merge from the provisions of the Convention. Maybe the compliance route is not definitively closed though and adaptations similar to the way the Convention on International Trade in Endangered Species of Wild Flora and Fauna (CITES) (which does not have a compliance mechanism) is using the conference of the parties to address non-compliance could work in the LosC context too. ${ }^{122}$

In general, there are very few legal tools specifically elaborated for the purpose of enforcing obligations erga omnes in international law. ${ }^{123}$ And although there seem to be more and more claims involving communitarian obligations, these are still in the form of bilateralized cases. ${ }^{124}$ The recent attempt by the Republic of the Marshall Islands is a case in point. ${ }^{125}$ These limitations of international adjudication are attributed to the decentralized structure of international law. Certain areas of international law may not function effectively if they remain decentralized (as for example international environmental law, where compliance control is the preferred route) or, put another way, unless they are partly centralized with particular types of enforcement available (as for example in the WTO). Enforcement mechanisms are, thus, evolving in different ways in the various sectoral regimes of international law, often departing from the mechanisms available under general international law. Different types of rules should entail different types of enforcement or compliance rules. Obligations erga omnes necessitate the development of appropriate avenues for their realization and they seem to be

Convention Against Torture; also, complaint procedures in the Inter-American Court of Human Rights and European Court of Human Rights conventions.

121 Reference to Boyle's cafeteria approach: Boyle (1997), 40; Of course, one could counter argue that, at the time, the experience and the practice of compliance bodies were scarce.

122 For the law of the sea, the discussion on the law of the sea in the UN GA has a similar function.

123 Tanaka (2011), supra note 24, 333-338; Pulp Mills case, Joint Diss. Op. of Judges Al-Khasawneh and B. Simma; Villalpando, supra note 12, 410; Tanaka (2011), supra note 24, 336; Crawford (2011), supra note 35, 226.

124 Reference can be made to the East Timor and Belgium $v$. Senegal cases, as well as to the Whaling in the Antarctic and the Air Spraying cases; Crawford (2013), 78; see also Crawford (2011), supra note 35, 228.

125 Marshall Islands v. India (Application) (2014) paras. 35-36; Marshall Islands v. Pakistan (2014) (Application) (2014), para. 2; Marshall Islands v. United Kingdom (Application) (2014); Memorial of the Marshall Islands, 16 March 2015, p. 98, para. 231; see also E. de Wet, "Invoking Obligations Erga Omnes in the 21st century: Progressive Developments since Barcelona Traction", 37 S.A.Y.I.L. (2013). 
in need of (centralized) collective action - not an easy task in the decentralized international legal system. ${ }^{126}$

\section{Acknowledgments}

[Eirini Fasia is a DPhil candidate in Public International Law at the University of Oxford (St. Anne's College), with the kind support of the Onassis Foundation Graduate Scholarship.] Many thanks are due to my supervisors, Professor Catherine Redgwell and Professor Antonios Tzanakopoulos, for their comments and feedback. Any possible errors remain my own.

126 Many scholars saw a paradigm shift in the emergence of obligations erga omnes, an ongoing process of constitutionalizing international law. However, such a development has not yet taken place. See, inter alia, A. von Bogdandy et al., 28(1) E.J.I.L. (2017), 115; A. Peters, "Global Constitutionalism: The Social Dimension", in T. Suami et al. (eds.), Global Constitutionalism from European and East Asian Perspectives (CUP, 2018); V.P. Tzevelekos, L. Lixinski, "Towards a Humanized International 'Constitution'?", 29 L.J.I.L. (2016), 343; E. de Wet, "The International Constitutional Order", 55 I.C.L.Q. (2006), 51; Cf. Tams (2005), supra note 6, 333; P.M. Dupuy, "Back to the Future of a Multilateral Dimension of the Law of State Responsibility for Breaches of 'Obligations Owed to the International Community as a Whole"', 23(4) E.J.I.L. (2012), 1059. 